\title{
Exposure to ethylene glycol ethers and spermatogenic disorders in man: a case-control study
}

\author{
H Veulemans, O Steeno, R Masschelein, D Groeseneken
}

\begin{abstract}
A case-control study was conducted among first time patients at a clinic for reproductive disorders. The study group consisted of 1019 cases, defined as patients diagnosed infertile or subfertile on the basis of a spermiogram and 475 controls who were diagnosed as normally fertile by the same procedure. Possible exposure to ethylene glycol ethers was assessed by the presence of the urinary metabolites methoxyacetic acid (MAA) and ethoxyacetic acid (EAA) respectively for 2 -methoxyethanol and 2-ethoxyethanol or their acetates. In total, EAA was detected in 39 cases and six controls, with a highly significant odds ratio of $3 \cdot 11(p=0.004)$. On the other hand, MAA was only found in one case and two controls. The presence of EAA in urine proved to be strongly associated with exposure to preparations containing solvents, especially paint products, and with some groups of occupations, the most important of which were also directly or possibly connected with paint products. The absence of a significant correlation between the concentration of urinary EAA and the various measures of sperm quality could be explained by the expected latent period between exposure and observed effects. Other temporal aspects of the relation between exposure as judged from the presence of urinary EAA and diagnosis are also discussed.
\end{abstract}

(British Journal of Industrial Medicine 1993;50:71-78)

Ethylene glycol ethers constitute an important class of organic solvents in paints, printing inks, and thinners, and have many other applications. In recent years, animal studies have indicated a considerable reproductive toxicity for 2-methoxyethanol (2-ME), 2-ethoxyethanol (2-EE), and their acetates in both males and females. ${ }^{1-3}$

Afd Arbeids en Verzekeringsgeneeskunde, KU Leuven, Kapucijnenvoer 35/5, B-3000 Leuven, Belgium

$H$ Veulemans, $R$ Masschelein, D Groeseneken

Afd Experimentele Geneeskunde-Endocrinologie, KU Leuven, Herestraat 49, B-3001 Leuven, Belgium O Steeno
The cytotoxic effects leading to testicular atrophy and impaired fertility have been extensively studied in animals. ${ }^{4-26}$ The most sensitive target cell appears to be the primary spermatocyte in the dividing and in the early and late pachytene stages, ${ }^{6-8132426}$ although other cell types, including perhaps spermatogonia, may also be affected under prolonged exposure to high doses. ${ }^{713}$ The degeneration of the germinal epithelium is reflected by a reduced sperm count, a reduction in testicular weight, a decreased sperm motility, and increased numbers of abnormal sperm forms.

Limited data are available on spermatotoxic effects in man. A small study among workers involved in the manufacture and packaging of 2-ME possibly showed a smaller testicular size in six exposed subjects compared with nine controls. ${ }^{27}$ In a larger study among 73 shipyard painters exposed to $2-\mathrm{ME}$ and 2-EE, an increased prevalence of oligozoospermia and azoospermia and an increased odds ratio (OR) for a lower sperm count per ejaculate were found relative to 40 non-exposed workers at the same shipyard.$^{28}$ Another cross sectional study conducted among 37 workers exposed to 2-EE in metal casting and 39 non-exposed subjects from the same plant showed a lower average sperm count per ejaculate among the exposed workers and some differences in the proportions of abnormal sperm shapes. ${ }^{29}$ Although these studies do not conclusively indicate exposure related effects in man their results are nevertheless compatible with animal data.

There is abundant evidence that it is not the ethylene glycol ethers themselves but their metabolites that are responsible for the spermatotoxic effects. ${ }^{12-14} 192024$ Among the most likely proximal toxins are methoxyacetic acid (MAA) for 2-ME and its acetate and ethoxyacetic acid (EAA) for 2-EE and its acetate. These alkoxyacids were identified as main metabolites in humans under conditions of experimental exposure. ${ }^{30-33}$ Moreover, these experiments showed comparatively long biological half lives for MAA (77.1 h) and EAA (21-42 h) after a single short term exposure. These long half lives could be relevant in terms of human toxicity because they would imply accumulation of the metabolites in subjects undergoing repeated daily exposure. This has been confirmed for EAA in field studies among occupationally exposed workers. ${ }^{34} 35$ 
The fact that EAA could be detected in urine after a prolonged non-exposure period of 12 days $^{35}$ was an important element in the design of the present casecontrol study. Since the effects seem to be largely reversible in animals, ${ }^{13161724}$ it was conceivable that exposure within a spermatogenic cycle would be of primary importance and that the presence of demonstrable amounts of urinary metabolites would indicate such exposure. The aim of this study was, therefore, to investigate the possible association between spermatogenic disorders in man and exposure to ethylene glycol ethers as assessed by the presence of the urinary metabolites.

\section{Methods}

STUDY GROUP .

The study group consisted of 1019 cases and 475 controls. All subjects were first time patients presenting at the university outpatients clinic for reproductive disorders in the period between October 1985 and July 1990. At this clinic for couples with reproductive problems, the routine procedure was that both the male and female partner were medically examined. Men who were clinically diagnosed as infertile or subfertile have been taken as cases. The controls represented male patients from the same clinic who were diagnosed as normally fertile.

\section{CLINICAL DIAGNOSIS}

All diagnoses were made by the same experienced clinician according to multiple criteria and were based on a complete spermiogram including ejaculate volume, sperm count, motility, vitality, morphology, and functional integrity of the cell membrane. The diagnoses were made without knowledge of the results of the urine tests.

Other medical data included plasma FSH concentration, period of abstinence from sexual activity before the examination, presence or absence of varicocele, drinking and smoking habits, and testicular volume.

\section{QUESTIONNAIRE}

Before the medical examination patients were given a questionnaire about their past and present occupations. The questionnaire also presented a list of chemical substances and product categories (see table 5), which were selected from a recent review of industrial spermatotoxic agents ${ }^{36}$ and from preparations likely to contain ethylene glycol ethers. Patients were asked to indicate regular exposures both within and outside their occupation.

\section{URINE ANALYSIS}

Urine samples taken on the day of the medical examination were analysed for MAA and EAA by gas chromatographic methods described previously. ${ }^{37} 38$
The laboratory personnel had no knowledge of the diagnoses made in the clinic. All samples considered to be positive on the basis of matching retention times were subsequently reanalysed by gas chromatography/mass spectrography (Hewlett Packard 5890 GC and 5970 Mass Selective Detector) using the pentafluorobenzyl (PFB) derivative technique. ${ }^{38}$ Mass spectra at the appropriate retention times were compared with reference spectra of the PFB-esters of the pure compounds obtained with the same method and instrument. Only urine samples with matching spectra were considered positive in the final analysis. The use of mass spectrography in full scan mode resulted in a detection limit of about $1 \mathrm{mg} / 1$.

\section{DATA ANALYSIS}

Data from the questionnaire relating to occupation, industry, employment, economic position, social class, and socioeconomic group were scored according to the 1980 classification of occupations and coding index, office of population censuses and surveys, London.

Statistical analysis was carried out on a Hewlett Packard 9816 computer with our own software and the HP 98820A statistical library. Unless stated otherwise, Fisher's exact test was used to interpret all $2 \times 2$ contingency tables. The Mantel-Haenszel method for stratified data was used to test for significance after controlling for possible confounders. Test results were interpreted as not significant above a 0.05 level.

\section{Results}

AGE, SOCIOECONOMIC GROUP AND LIFESTYLE

The mean age of the case was 29.1 (SD 4.5 range 20-56) and of the controls $29 \cdot 5$ (SD 4.4, range 2049). These were not significantly different. Their distribution over different socioeconomic groups was essentially the same ( $\chi^{2}$ probability $0 \cdot 82$ ).

Anamnestical information was used to score the subjects into three categories for alcohol consumption and into four categories of smokers. Alcohol consumption was the same in cases and controls $\left(\chi^{2}\right.$ probability 0.67$)$. The difference in smoking habits was not significant $\left(\chi^{2}\right.$ probability $\left.0 \cdot 14\right)$, with only a slight excess of heavy smokers ( $>25$ cigarettes per day) among controls ( 16 observed $v 11 \cdot 2$ expected).

\section{CLINICAL PARAMETERS}

The clinical parameters were compared by one way analysis of variance (table 1). As should be expected from the definition of the case and control group, highly significant differences were found for testis volume, sperm motility, vitality, concentration, morphology, and integrity of the cell membrane, and FSH concentration. The mean ejaculate volume and period of abstinence from sexual activity did not differ significantly. 
Table 1 Clinical parameters

\begin{tabular}{|c|c|c|c|}
\hline & $\begin{array}{l}\text { Cases }(n=1019) \\
\text { mean }(S D)\end{array}$ & $\begin{array}{l}\text { Controls }(n=475) \\
\text { mean }(S D)\end{array}$ & \\
\hline $\begin{array}{l}\text { Mean testis volume }(\mathrm{ml} \\
\text { Ejaculate volume } \mathrm{ml} \\
\text { Sperm motility }(\% \text { normal }) \\
\text { Vitality } \% \text { living } \\
\text { Concentration }\left(10^{6} \mathrm{ml}\right) \\
\text { Morphology } \% \text { normal }) \\
\text { Integrity cell membrane (\% normal) } \\
\text { FSH (mIE ml) } \\
\text { Abstinence (days) }\end{array}$ & $\begin{array}{l}17 \cdot 6(6 \cdot 4) \\
3 \cdot 5(1 \cdot 7) \\
42 \cdot 9(21 \cdot 3) \\
50 \cdot 7(15 \cdot 9) \\
18 \cdot 1(25 \cdot 3) \\
52 \cdot 2(13 \cdot 3) \\
53 \cdot 2(12 \cdot 9) \\
7 \cdot 6(9 \cdot 7) \\
4 \cdot 7(2 \cdot 6)\end{array}$ & $\begin{array}{l}20 \cdot 8(5 \cdot 3) \\
3.4(1.6) \\
73.6(11 \cdot 9) \\
60 \cdot 6(13.5) \\
72 \cdot 5(43.3) \\
63.9(7 \cdot 3) \\
62 \cdot 8(9 \cdot 4) \\
4.4(2 \cdot 9) \\
4.9(2 \cdot 8)\end{array}$ & $\begin{array}{l}\star \star \star \star \\
N S \\
\star \star \star \star \\
\star \star \star \star \\
\star \star \star \star \\
\star \star \star \star \\
\star \star \star \star \\
\star \star \star \star \\
\text { NS }\end{array}$ \\
\hline
\end{tabular}

$\star \star \star \star \mathrm{p}<0.0001$.

\section{METABOLITES}

In total, urinary EAA was detected in 45 subjects, with concentrations ranging from 1.3 to $71.0 \mathrm{mg} / 1$ (table 2). Of these, 39 were cases and six were controls. This gave a highly significant OR $(3 \cdot 11$; $\mathrm{p}=0.004)$. The mean EAA concentration, on the other hand, showed no significant difference between the two groups. Of the concentrations above $10 \mathrm{mg} / \mathrm{l}$, 10 were cases and two were controls. The highest value $(71.0 \mathrm{mg} / \mathrm{l})$ was in one of the case group, but the second and third highest concentrations were in controls (60.8 and $51.5 \mathrm{mg} / \mathrm{l}$ ).

On dividing the study group according to sperm concentration corrected for motility and morphology (table 3), a highly significant clustering of EAA positive patients was found among the subcategories representing complete azoospermia and severe oligozoospermia ( $\chi^{2}$ probability $0 \cdot 0087$ ).

In linear regression analysis, EAA concentrations did not correlate significantly with any of the clinical parameters. On the other hand, a significant negative correlation was found between EAA concentration

Tabie 2 Numbers of cases and controls with positive identification of $E A A$ or $M A A$ in urine

\begin{tabular}{lllll}
\hline & $\begin{array}{l}\text { Cases } \\
n=1019\end{array}$ & $\begin{array}{l}\text { Controls } \\
n=475,\end{array}$ & OP. & p Value \\
\hline EAA & 39 & 6 & 3.11 & 0.004 \\
MAA & 1 & 2 & 0.23 & NS \\
Total & 40 & 8 & 2.39 & 0.013 \\
\hline
\end{tabular}

Table 3 Distribution of EAA positive subjects in subgroups defined by the concentration of sperm with normal motility and morphology

\begin{tabular}{lll}
\hline $\begin{array}{l}\text { Sperm concentration } \\
\left(10^{6} \mathrm{ml}\right)\end{array}$ & $\begin{array}{l}\text { EAA positive } \\
\text { subjects }\end{array}$ & Total \\
\hline 0 & 11 & 151 \\
$>0-<10$ & 24 & 738 \\
$10-<20$ & 4 & 234 \\
$20-<40$ & 4 & 205 \\
$\geqslant 40$ & 2 & 166 \\
\hline
\end{tabular}

$\gamma^{2}$ probability 0.0087 and age $(r=-0.30, \mathrm{p}<0.05)$. Within the total cases group the average age of the EAA positive patients $(27 \cdot 3)$ was slightly but significantly lower than in the negative patients $(29.2)(p=0.01)$. A similar, but statistically non-significant, difference was found for the controls (28.3 $v 29.5)$.

The metabolite MAA was positively identified in only three urine samples (table 2 ), representing one case $(3.2 \mathrm{mg} / \mathrm{l})$ and two controls $(2 \cdot 1$ and $2.3 \mathrm{mg} / \mathrm{l})$. The total number of 40 positive EAA or MAA cases $v$ eight controls still gave a significant OR of 2.39 $(\mathrm{p}=0.013)$. Because the number of positive MAA was too small, they were omitted from further analysis related to occupation and contact with chemical products.

\section{OCCUPATION AND INDUSTRY}

The case and control subjects were grouped according to occupation and industry (table 4). Odds ratios greater than one were found in several categories, but none proved statistically significant. The highest ORs were found among paint workers (2.35), wood workers (1.88), car assembly workers (1.71), and welders $(1.61)$

A large number of EAA positive subjects appeared to be clustered in only a few occupations (table 5). Categories with a significant excess in this respect were paint workers (six positive subjects among a total of $18 ; p<0.0001$ ), motor mechanics, and car body repairers (five in $29 ; \mathrm{p}=0.0015$ ), and wood workers (three in 25; $\mathrm{p}=0.039$ ). The adopted coding system did not always allow the expression of possibly relevant similarities in exposure conditions between different occupations. Notable examples of this were found among EAA positive subjects. At least two more subjects could be associated with printing, one in the production of metal packaging goods and the other in planning the production of publicity stickers. Likewise, not represented among the motor mechanics and car body repairers were a transport manager also doing repair and maintenance and a comparable case in an army transportation unit. Further examples were a laboratory scientist in a paint factory, a planning manager in office decorating 
Table 4 Diagnosis group and occupation or industry

\begin{tabular}{|c|c|c|c|}
\hline Occupation or industry & Cases $(n=1019)$ & Controls ( $n=475)$ & OR \\
\hline $\begin{array}{l}\text { Agriculture, horticulture } \\
\text { Food processing } \\
\text { Leather and textile }\end{array}$ & $\begin{array}{r}22 \\
21 \\
6\end{array}$ & $\begin{array}{l}9 \\
8 \\
2\end{array}$ & $\begin{array}{l}1 \cdot 14 \\
1 \cdot 23 \\
1 \cdot 40\end{array}$ \\
\hline $\begin{array}{l}\text { Electricians, electronics industry } \\
\text { Metal workers (unfinished products) }\end{array}$ & $\begin{array}{l}20 \\
37\end{array}$ & $\begin{array}{r}9 \\
23\end{array}$ & $\begin{array}{l}1 \cdot 04 \\
0 \cdot 74\end{array}$ \\
\hline $\begin{array}{l}\text { Metal workers (finished products) } \\
\text { Welders } \\
\text { Car assembly workers } \\
\text { Motor mechanics, car body repairers } \\
\text { Other }\end{array}$ & $\begin{array}{r}136 \\
24 \\
29 \\
18 \\
65\end{array}$ & $\begin{array}{r}60 \\
7 \\
8 \\
11 \\
34\end{array}$ & $\begin{array}{l}1 \cdot 06 \\
1.61 \\
1 \cdot 71 \\
0 \cdot 76 \\
0 \cdot 88\end{array}$ \\
\hline $\begin{array}{l}\text { Wood, paper, printing workers } \\
\text { Wood workers } \\
\text { Paper and printing }\end{array}$ & $\begin{array}{l}36 \\
20 \\
16\end{array}$ & $\begin{array}{r}12 \\
5 \\
7\end{array}$ & $\begin{array}{l}1 \cdot 41 \\
1 \cdot 88 \\
1 \cdot 07\end{array}$ \\
\hline $\begin{array}{l}\text { Glass, ceramics, chemicals, plastics, paints } \\
\text { Paint production workers, painters, decorators } \\
\text { Glass, ceramics workers } \\
\text { Rubber and plastic workers } \\
\text { Other }\end{array}$ & $\begin{array}{r}42 \\
15 \\
6 \\
8 \\
13\end{array}$ & $\begin{array}{r}21 \\
3 \\
3 \\
5 \\
10\end{array}$ & $\begin{array}{l}0 \cdot 93 \\
2 \cdot 35 \\
0 \cdot 93 \\
0 \cdot 74 \\
0 \cdot 60\end{array}$ \\
\hline $\begin{array}{l}\text { Construction, mining } \\
\text { Construction workers } \\
\text { Coal miners }\end{array}$ & $\begin{array}{l}66 \\
45 \\
21\end{array}$ & $\begin{array}{l}29 \\
18 \\
11\end{array}$ & $\begin{array}{l}1 \cdot 07 \\
1 \cdot 17 \\
0 \cdot 89\end{array}$ \\
\hline $\begin{array}{l}\text { Transportation } \\
\text { Managers } \\
\text { Education, welfare workers } \\
\text { Science, engineering } \\
\text { Clerical professions } \\
\text { Salesmen } \\
\text { Hotels, cleaning, personal services } \\
\text { Armed forces, police } \\
\text { Other }\end{array}$ & $\begin{array}{r}76 \\
113 \\
88 \\
71 \\
127 \\
55 \\
20 \\
54 \\
29\end{array}$ & $\begin{array}{r}40 \\
41 \\
47 \\
39 \\
76 \\
23 \\
9 \\
17 \\
10\end{array}$ & $\begin{array}{l}0.88 \\
1 \cdot 32 \\
0 \cdot 86 \\
0 \cdot 84 \\
0 \cdot 75 \\
1 \cdot 12 \\
1.04 \\
1 \cdot 51 \\
1 \cdot 36\end{array}$ \\
\hline
\end{tabular}

Table 5 Clusters of EAA positive subjects and occupation

\begin{tabular}{lcc}
\hline & $\begin{array}{c}\text { Total number } \\
(n=1494)\end{array}$ & $\begin{array}{c}\text { EAA positive subjects } \\
(n=45)\end{array}$ \\
Occupation & 48 & 5 \\
Wood, paper, printing workers & 3 & 2 \\
Wood & 25 & 12 \\
Paper and printing & 23 & 1 \\
Metal workers (finished products) & 196 & 3 \\
Welders & 31 & 5 \\
Car assembly workers & 37 & 3 \\
Motor mechanics, car body repairers & 29 & 8 \\
Other & 99 & 6 \\
Glass, ceramics, chemicals, plastics, paints & 63 & 1 \\
Paint production workers, painters, decorators & 18 & 1 \\
Glass, ceramics workers & 9 & \\
Rubber and plastic workers & 13 & \\
Other & 23 & 4 \\
Managers & 154 & 4 \\
Scientists, engineers & 110 & 4 \\
Salesmen & 78 & 4 \\
Other & 845 & 4 \\
\hline
\end{tabular}

${ }^{\star} \mathrm{p}<0.05 ;{ }^{\star \star} \mathrm{p}=0.01 ;{ }^{\star \star \star} \mathrm{p}<0.001 ;{ }^{\star \star \star \star} \mathrm{p}<0.0001$.

and furnishing, and a welder in a coach assembly plant.

Of the EAA positive subjects, 42 were in the same employment for at least one year before the medical examination. The remaining four (all cases) had changed employment some months earlier but two of them reported doing the same or similar work in previous jobs.

\section{CHEMICAL PRODUCTS}

Table 6 summarises the numbers of subjects with regular exposure to the various products or product categories in the questionnaire. The ORs for occupationally exposed cases were considerably less than unity for cadmium $(0.28, p=0.013)$, textile dyes $(0.33, p=0.061)$, and carbon disulphide $(0.50$, $\mathrm{p}=0 \cdot 11)$. Roughly the same results were found 
Table 6 Diagnosis and occupational exposure to chemical products, or a combination of occupational and/or other exposure (in parentheses)

\begin{tabular}{|c|c|c|c|}
\hline & $\begin{array}{l}\text { Cases } \\
(n=1019)\end{array}$ & $\begin{array}{l}\text { Controls } \\
(n=475)\end{array}$ & $O R$ \\
\hline $\begin{array}{l}\text { Lead } \\
\text { Cadmium } \\
\text { Tin } \\
\text { Welding fumes }\end{array}$ & $\begin{array}{c}67(87) \\
6(7) \\
53(62) \\
132(172)\end{array}$ & $\begin{array}{l}24(39) \\
10(10) \\
19(25) \\
73(102)\end{array}$ & $\begin{array}{l}1 \cdot 32(1.04) \\
0 \cdot 28^{\star}(0.32)^{\star} \\
1 \cdot 31(1 \cdot 16) \\
0.82(0.74)\end{array}$ \\
\hline $\begin{array}{l}\text { Insecticides/pesticides } \\
\text { Weed killers } \\
\text { Antiseptics }\end{array}$ & $\begin{array}{l}28(156) \\
37(239) \\
80(111)\end{array}$ & $\begin{array}{l}16(76) \\
17(105) \\
33(49)\end{array}$ & $\begin{array}{l}0.81(0.95) \\
1.01(1.08) \\
1.14(1.06)\end{array}$ \\
\hline $\begin{array}{l}\text { Paints, varnishes } \\
\text { Thinners } \\
\text { Paint removers }\end{array}$ & $\begin{array}{r}126(475) \\
127(278) \\
56(158)\end{array}$ & $\begin{array}{l}42(209) \\
57(111) \\
17(74)\end{array}$ & $\begin{array}{l}1.45(1.11) \\
1.04(1.23) \\
1.56(0.99)\end{array}$ \\
\hline $\begin{array}{l}\text { Printing inks } \\
\text { Glues } \\
\text { Solvents } \\
\text { Degreasers, cleaning products } \\
\text { Petroleum products, fuels }\end{array}$ & $\begin{array}{r}40(47) \\
103(201) \\
87(107) \\
189(272) \\
150(251)\end{array}$ & $\begin{array}{l}19(25) \\
44(80) \\
46(60) \\
97(129) \\
66(111)\end{array}$ & $\begin{array}{l}0.98(0.87) \\
1.10(1.21) \\
0.87(0.81) \\
0.89(0.97) \\
1.07(1.07)\end{array}$ \\
\hline
\end{tabular}

${ }^{\star} \mathrm{p}<0.05$.

when the non-occupational exposures were also included. The numbers in each of these categories were, however, small. Several other product categories gave ORs greater than unity. Of these, occupational exposures to leather finishing products gave the highest estimate (2.33). This result was, however, not statistically significant $(p=0.67)$ because of the small number of exposed subjects. Possibly of more importance were the occupational exposures to paints and varnishes $(O R=1.45$, $p=0.053)$ and paint removers $(O R=1.56$, $\mathrm{p}=0 \cdot 12$ ).

The data of the questionnaire were also compared with the results of the urine analysis, and showed a strong association between exposure to paint products and the detection of urinary EAA (table 7).

Table 7 The number of $E A A$ positive subjects with occupational exposure to chemical products, or a combination of occupational and/or other exposure (in parentheses)

\begin{tabular}{lll}
\hline Products & \multicolumn{2}{c}{$\begin{array}{l}\text { Number of EAA positive } \\
\text { subjects (total }\end{array}=45$ ) } \\
\hline Paints, varnishes & $17^{\star \star \star \star}$ & $\left(29^{\star}\right)$ \\
Thinners & $18^{\star \star \star \star}$ & $\left(23^{\star \star \star}\right)$ \\
Paint removers & $11^{\star \star \star \star}$ & $\left(16^{\star \star \star}\right)$ \\
Total for paint products & $20^{\star \star \star \star}$ & $\left(32^{\star \star}\right)$ \\
Printing inks & 4 & $(4)$ \\
Glues & $11^{\star \star}$ & $\left(15^{\star}\right)$ \\
Solvents & $9^{\star}$ & $(9)$ \\
Degreasers/cleaning products & $15^{\star}$ & $(17)$ \\
Petroleum products, fuels & $12^{\star}$ & $(15)$ \\
Total for all preparations containing & & \\
solvents & $29^{\star \star \star}$ & $\left(38^{\star \star}\right)$ \\
\hline
\end{tabular}

${ }^{\star} \mathrm{p}<0.05 ;{ }^{\star \star} \mathrm{p}<0.01 ;{ }^{\star \star \star} \mathrm{p}<0.001^{\star} ; \star \star \star \star \mathrm{p}<0.0001$.
Smaller but nevertheless significant correlations were found between detectable urinary EAA and occupational exposure to glues $(p=0.004)$, solvents $(p=0.017)$, degreasers and cleaning products $(p=0.020)$, and petroleum products and fuels $(p=0.027)$. Obviously these results should not be interpreted as totally independent of each other, as mutually strong correlations were also found between exposures to the different categories of paint products, and between paint products and the other groups. Taking account of all categories a significant majority of 29 out of 45 EAA positive subjects reported occupational exposure to solvent related products. The total number of these subjects with regular contact with these products within or outside their occupation was 38 .

Lead, cadmium, insecticides, weed killers, asphalt and bitumen, carbon disulphide, and welding fumes were also treated as possible confounders. The association between urinary EAA and diagnosis remained significant after stratification for exposure to any of these product categories ( $\chi^{2}$ probability: $0 \cdot 011$ ).

\section{Discussion}

We chose a case-control approach to study possible spermatoxic effects of ethylene glycol ethers in man for two reasons.

Firstly, although exposure to ethylene glycol ethers may have been common both within and outside industrial environments at the time this study was initiated, single large cohorts of exposed subjects were not available for a cross sectional type of study. From our own experience ${ }^{39}$ it seemed that the 
exposed population consisted mainly of small groups of workers in minor enterprises such as printing shops or garages, or in small departments of the larger companies. A cross sectional study would have posed major problems under these circunstances, especially for the selection of suitable control groups and the standardisation of a sperm testing protocol. A case-control design, on the other hand, seemed more appropriate to avoid these problems. By taking all first time patients from the same clinic, we believed that selection bias could be minimised. The results support this view, as cases and controls were within the same age group and had a similar socioeconomic background. Another important consideration was that all testing of sperm could be done in a clinical setting and in a highly standardised manner.

Secondly, a case-control study was preferred because of the anticipated low participation rates in an industrial survey involving testing of sperm. Other epidemiological studies reported participation rates of $50 \%$ for exposed subjects and as low as $25-32 \%$ for controls, ${ }^{2829}$ weakening these studies by the possibility of selection bias.

The main difficulty with the case-control design was to obtain reliable information on exposure to specific ethylene glycol ethers. Such information could not be obtained by a questionnaire alone, because most patients would not have sufficiently detailed knowledge of the composition of products. The availability of a specific test for urinary metabolites offered an alternative. Because of the fairly long biological half lives of the metabolites, detection of exposure would be possible until several days after the last contact. ${ }^{35}$ As the medical examinations took place in the middle of the week and no patients were in hospital, it seemed reasonable to expect that most urine tests would reflect exposure as a consequence of the subject's normal daily activities. The probability of being found positive would be higher in persons with regular exposure. Because accumulation of the metabolites takes place under daily exposure during a working week, urinary metabolite concentrations in such persons would be more likely to exceed the detection limit, even if no exposure took place on the day of the medical examination or even on preceding days.

The total sample population size was bused on the assumption that the number of exposed subjects would not be less than $0.5 \%$. The actual number $(3.2 \%)$ does not necessarily reflect the exposure in the population at large, but rather the increased exposure odds among our cases.

The main finding was the highly significant association between a diagnosis of impaired fertility and the detection of EAA in urine. Furthermore, the occurrence of EAA was strongly associated with exposure to products containing solvents, especially paint products, and with some groups of occupa- tions. The most important of these groups were also directly or possibly connected with paint products. Association with printing inks, on the other hand, was only reported by four of the EAA positive patients. Other sources could not be singled out because of the strong correlation between exposure to paint products and preparations containing solvents. The fact that EAA was found in 45 patients whereas MAA was only found in three patients seems to agree with available statistical data on the use of the parent compounds in chemical formulations. ${ }^{40}$

The choice of the study population must be taken into account when suggesting a possible causal relation between exposure and clinical condition. Normally, patients would only be referred to the clinic after a long period of unsuccessful reproduction. One possibility is that exposure to the spermatotoxic agent occurred frequently or continuously during that period. The data contain no direct proof of this hypothesis, but the fact that only four of the EAA positive patients had changed employment within one year before the medical examination, lends support to this explanation for at least part of the cases. It is also conceivable that exposure acted only as a contributing factor in some cases with an already subnormal fertility. Compatible with this view is the finding of a high proportion of azoospermias among EAA positive patients. A plausible explanation for this would be the exacerbation of a pre-existing condition by the exposure. In such cases, even more recent exposure could have affected the clinical appearance.

For the interpretation of the results it is also important to consider the latent period between exposure and possible spermatotoxic effects. If, as is the case in animals, the toxic effects manifest themselves in the early stages of spermatogenesis, a latent period of about 10 weeks should be taken into account between the onset of the exposure and clinical disturbances in the spermiogram. This latent period could distort the results of this study in two ways. Firstly, exposure related cases could still be found several weeks after the last contact with 2-ME, 2-EE, or their acetates, when urinary metabolites would no longer be detectable. Secondly, urinary metabolites could have come from exposures too recent or too weak to have any possible connection with the patient's clinical condition. If it is correct to assume that "false positive" findings of this kind were equally likely to occur in the cases and controls, then this would lead to a weakening of the statistical power of the study. Since the first type of error, that of a false negative result, only applied to the case group, it would also tend to weaken the power. Therefore, if exposure to ethylene glycol ether is causally related to some of the spermatogenic disorders, the overall effect of the latent period would probably result in an underestimation of this relation. 
A further point of interpretation concerns the concentrations of urinary metabolites and their relation to the level of exposure. Without more information on frequency and duration of exposure and the time lapse between the last exposure and the medical examination, it is impossible to evaluate directly the exposure levels from the concentrations of metabolites. Indeed, even the lowest detectable amounts could conceivably represent the remaining traces of a considerable exposure some time previously. Furthermore, when trying to relate the concentrations of metabolites to the clinical parameters, one should also be aware of the distorting influence of the latent period as discussed. It is therefore not surprising that no significant correlations were found between urinary EAA concentrations and the various measures of sperm quality. The only finding in the sense of a dose response relation was the excess of azoospermia in the EAA positive subgroup of cases. The excess seemed most prominent among patients with the highest EAA values. This finding may have some relevance, as a cross sectional study in shipyard painters also showed an increased proportion of azoospermia. In exposed painters $5 \%$ were found with azoospermia, $v$ only $1 \%$ expected on the basis of population surveys. ${ }^{28}$

In the earlier cross sectional studies the time weighted exposures were on average $2.7 \mathrm{ppm}$ for 2 -EE and $0.8 \mathrm{ppm}$ for $2-\mathrm{ME}$ in shipyard painters, ${ }^{28}$ and $6.6 \mathrm{ppm}$ for 2 -EE in metal casting workers. ${ }^{29}$ In the shipyard study it is uncertain whether these concentrations correctly represent usual or previous exposures. Also the possibility of dermal exposure has to be taken into account in both studies. In the metal casting study the urinary EAA concentrations, ranging from non-detectable to $163 \mathrm{mg} / \mathrm{g}$ creatinine, seem, however, to agree reasonably well with the measured air concentrations. Although the urinary EAA values in our study do not permit a direct assessment of the doses involved, it should nevertheless be noted that the range of concentrations found is not incompatible with exposures of the same order of magnitude as in the cross sectional studies.

We gratefully acknowledge the excellent technical assistance of Ms $\mathrm{H}$ Janssens, Ms $\mathrm{N}$ Van Nimmen, and Ms $\mathrm{K}$ Vranckx. This work was supported by ECETOC, the Belgian Ministries for Labour and Public Health, and the Nationale Loterij.

Requests for reprints to: $\mathrm{H}$ Veulemans, Afd Arbeids-en Verzekeringsgeneeskunde, $\mathrm{K}$ U Leuven, Kapucijnenvoer 35/5, B-3000 Leuven, Belgium.

1 Ecetoc. The toxicology of ethylene glycol monoalkyl ethers and its relevance to man. Brussels: Ecetoc, 1982. (Technical report No 4.)

2 Ecetoc. The toxicology of glycol ethers and its relevance to man: an up-dating of technical report No 4. Brussels: Ecetoc, 1985. (Technical report No 17.)

3 Hardin BD. Reproductive toxicity of the glycol ethers. Toxicology 1983;27:91-102.

4 Anderson D, Brinkworth MH, Jenkinson PC, Clode SA, Creasy DM, Gangolli SD. Effects of ethylene glycol monomethyl ether on spermatogenesis, dominant lethality, and $F_{1}$ abnormalities in the rat and the mouse after treatment of $F_{0}$ males. Teratogenesis Carcinog Mutagen 1987;7:141-58.

5 Barbee SJ, Terill JB, De Sousa DJ, Conaway CC. Subchronic inhalation toxicology of ethylene glycol monoethyl ether in the rat and rabbit. Environ Health Perspect 1984;57:157-63.

6 Chapin RE, Lamb JC. Effects of ethylene glycol monomethyl ether on various parameters of testicular function in the F344 rat. Environ Health Perspect 1984;57:219-24.

7 Chapin RE, Dutton SL, Ross MD, Lamb JC. Effects of ethylene glycol monomethyl ether on mating performance and epididymal sperm parameters in F344 rats. Fundam Appl Toxicol 1985;5:182-9.

8 Creasy DM, Foster PMD. The morphological development of glycol ether-induced testicular atrophy in rat. Exp Mol Pathol 1984;40:169-76.

9 Creasy DM, Flynn JC, Gray TJB, Butler WH. A quantitative study of stage-specific spermatocyte damage following administration of ethylene glycol monomethyl ether in the rat. Exp Mol Pathol 1985;43:321-36.

10 Doe JE, Samuels DM, Tinston DJ, De Silva Wickramaratne GA. Comparative aspects of the reproductive toxicology by inhalation in rats of ethylene glycol monomethyl ether and propylene glycol monomethyl ether. Toxicol Appl Pharmacol 1983;69:43-7.

11 Feuston MH, Bodnar KR, Kerstetter SL, Grink CP, Belcak MJ, Singer EJ. Reproductive toxicity of 2-methoxyethanol applied dermally to occluded and nonoccluded sites in male rats. Toxicol Appl Pharmacol 1989;100:145-61.

12 Foster PMD, Creasy DM, Foster JR, Thomas LV, Cook MW, Gangolli SD. Testicular toxicity of ethylene glycol monomethyl and monoethyl ethers in the rat. Toxicol Appl Pharmacol 1983;69:385-99.

13 Foster PMD, Creasy DM, Foster JR, Gray TJB. Testicular toxicity produced by ethylene glycol monomethyl and monoethyl ethers in the rat. Environ Health Perspect 1984;57: 207-17.

14 Foster PMD, Blacburn DM, Moore RB, Lloyd SC. Testicular toxicity of 2-methyoxyacetaldehyde, a possible metabolite of ethylene glycol monomethyl ether, in the rat. Toxicol Lett 1986;32:73-80.

15 Lamb JC, Dushyant KG, Russell VS, Hommel L, Sabharwal PS. Reproductive toxicity of ethylene glycol monoethyl ether tested by continuous breeding of CD-1 mice. Environ Health Perspect 1984;57:85-90.

16 Lee KP, Kinney LA, Valentine R. Comparative testicular toxicity of bis(2-methoxylethyl) ether and 2-methoxyethanol in rats. Toxicology 1989;59:239-58.

17 Lee KP, Kinney LA. The ultrastructure and reversibility of testicular atrophy induced by ethylene glycol monomethyl ether (EGME) in the rat. Toxicol Pathol 1989;17:759-73.

18 Miller RR, Ayres JA, Young JT, McKenna MJ. Ethylene glycol monomethyl ether. I. Subchronic vapor inhalation study with rats and rabbits. Fundam Appl Toxicol 1983;3:49-54.

19 Miller RR, Hermann EA, Young J T, Landry TD, Calhoun LL. Ethylene glycol monomethyl ether and propylene glycol monomethyl ether: metabolism, disposition and subchronic inhalation toxicity studies. Environ Health Perspect 1984;57:233-9.

20 Moss EJ, Thomas LV, Cook MW, Walters DG, Foster PMD, Creasy DM, Gray TJB. The role of metabolism in 2methoxyethanol-induced testicular toxicity. Toxicol Appl Pharmacol 1985;79:480-9.

21 Nagano K, Nakayama E, Koyano $M$, Oobayashi $M$, Adashi $M$, Yamada $T$. Testicular atrophy of mice induced by ethylene glycol monoalkyl ethers. Japanese Journal of Industrial Health 1979;21:29-35.

22 Nagano K, Nakayama E, Oobayashi $H$, Nishizawa T, Okuda $H$, Yamazaki $\mathrm{K}$. Experimental studies on toxicity of ethylene glycol ethers in Japan. Environ Health Perspect 1984;57:75-84.

23 Oudiz DJ, Zenick H, Nieuwenhuis RJ, McGinnis PM. Male reproductive toxicity and recovery associated with acute ethoxyethanol exposures in rats. $J$ Toxicol Environ Health 1984;13:763-75.

24 Oudiz D, Zenick $H$. In vivo and in vitro evaluations of spermatoxicity induced by 2-ethoxyethanol treatment. Toxicol Appl Pharmacol 1986;84:576-83. 
25 Samuels DM, Doe JE, Tinston DJ. The effects on the rat testis of single inhalation exposures to ethylene glycol monoalkyl ethers, in particular ethylene glycol monomethyl ether. Arch Toxicol 1984;(Suppl 7):167-70.

26 Zenick H, Oudiz D, Nieuwenhuis RJ. Spermatotoxicity associated with acute and subchronic ethoxyethanol treatment. Environ Health Perspect 1984;57:225-31.

27 Cook RR, Van Deenen PFD, Bodner KM, Dickson GS, Kolesar RC, Flanagan K. A cross-sectional study of ethylene glycol monomethyl ether process employees. Arch Environ Health 1982;37:346-51.

28 Welch LS, Schrader SM, Turner TW, Cullen MR. Effects of exposure to ethylene glycol ethers on shipyard painters: II. Male reproduction. Am J Ind Med 1988;14:509-26.

29 Ratcliffe JM, Schrader SM, Clapp DE, Halperin WE, Turner TW, Hornung RW. Semen quality in workers exposed to 2-ethoxyethanol. Br J Ind Med 1989;46:399-406.

30 Groeseneken D, Veulemans H, Masschelein R. Urinary excretion of ethoxyacetic acid after experimental human exposure to ethylene glycol monoethyl ether. Br J Ind Med 1986;43:615-9.

31 Groeseneken D, Veulemans H, Masschelein R, Van Vlem E Ethoxyacetic acid: a metabolite of ethylene glycol monoethyl ether in man. Br J Ind Med 1987;44:488-93.

32 Groeseneken D, Veulemans H, Masschelein R, Van Vlem E Comparative urinary excretion of ethoxyacetic acid in man and rat after single low doses of ethylene glycol monoethyl ether. Toxicol Lett 1988;41:57-68.
33 Groeseneken D, Veulemans H, Masschelein R, Van Vlem E. Experimental human exposure to ethylene glycol monomethyl ether. Int Arch Occup Environ Health 1989;61:243-7.

34 Angerer J, Lichterbeck E, Begerow J, Jekel S, Lehnert G. Occupational chronic exposure to organic solvents. XIII. Glycolether exposure during the production of varnishes. Int Arch Occup Environ Health 1990;62:123-6.

35 Veulemans H, Groeseneken D, Masschelein R, Van Vlem E. Field study of the urinary excretion of ethoxyacetic acid during repeated daily exposure to the ethyl ether of ethylene glycol and the ethyl ether of ethylene glycol acetate. Scand $J$ Work Environ Health 1987;13:239-42.

36 Steeno OP, Pangkahila A. Occupational influences on male fertility and sexuality. Andrologica 1984;16:5-22.

37 Groeseneken D, Van Vlem E, Veulemans H, Masschelein R. Gas chromatographic determination of methoxyacetic and ethoxyacetic acid in urine. Br J Ind Med 1986;43:62-5.

38 Groeseneken D, Veulemans H, Masschelein R, Van Vlem E. An improved method for the determination in urine of alkoxyacetic acids. Int Arch Occup Environ Health 1989;61:249-54.

39 Veulemans H, Groeseneken D, Masschelein R, Van Vlem E. Survey of ethylene glycol ether exposures in Belgian industries and workshops. Am Ind Hyg Assoc J 1987;48:671-6.

40 Johanson G, Rick U. Förekomst av glykoletrar i kemiska produkter i Sverige. Arbete och Hälsa, 1986;13:1-18.

Accepted 9 March 1992 